\title{
MAREVA INJUNCTION AS A PREVENTIVE RELIEF: THE MALAYSIAN EXPERIENCE
}

\author{
Zuraidah $A i^{*}$
}

\begin{abstract}
Mareva injunction generally results from a successful application to freeze the assets of the defendant prior to trial. In Malaysia, the application for the Mareva injunction did not get a good start, on the ground that the Malaysian court had no jurisdiction to grant such relief. The legal remedy under the Debtors Act 1957, by way of attachment of property before judgment was also an obstacle to the introduction of the Mareva injunction. It was only in 1984, in the case of Zainal Abidin v. Century Hotel Sdn Bhd, ${ }^{1}$ that such an application was granted when Raja Azlan CJ held that Mareva injunction should be available in Malaysia to fulfill modern commercial need. This paper examines the development of the Mareva injunction and its implementation in Malaysia. The research methodology which is adopted in this paper is mainly case law analysis. There will also be a brief appraisal of the application of Mareva injunction from the Shariah perspective.
\end{abstract}

Assistant Professor, Ahmad Ibrahim Kulliyyah of Laws, International Islamic University Malaysia.

1 [1982]1 MLJ 260. 


\title{
INTRODUCTION
}

The Mareva injunction has its origin in English law. It is worthy to note that the position in England before 1975 was that courts would not grant an injunction to restrain a defendant from disposing of his assets and it had never been the practice of the English courts to seize assets of a defendant before judgment, or to restrain their disposal. This is in line with the long established rule of English law that "you cannot get an injunction to restrain a man who is alleged to be a debtor from parting with his property."2 As Cotton LJ observed in Lister and Co. v Stubbs: ${ }^{3}$

\begin{abstract}
"I know of no case where, because it was highly probable that if the action were brought to a hearing the plaintiff could establish that a debt was due to him from the defendant, the defendant has been ordered to give security until that has been established by the judgment or decree.”
\end{abstract}

In other words, no injunction will be granted before trial and the only exception is in the case of fraud. This old traditional view was later removed with the introduction of a new way to prevent a defendant from disposing his assets prior to trial or judgment. This happened in 1975 when Lord Denning in two landmark cases of Nippon Yusen Kaisha v Karageorgis ${ }^{4}$ and Mareva Compania Naviera S.A v International Bulkcariers $S$. $\mathrm{A}^{5}$ granted such relief. In both cases, actions were brought by shipowners against charterers regarding unpaid hire. Although the charterers were out of the jurisdiction and could not be traced, they had some assets in London. The shipowners sought $e x$ parte injunctions, because they were afraid that the charterers might transfer the assets outside the jurisdiction before judgment could be passed, which could cause injustice to them. In a very short judgment Lord Denning stated:

\footnotetext{
2 Robinson v Pickering (1881) 16 Ch. D. 660. per James LJ.

3 (1890) 45 Ch.D. 1, at 13.

4 [1975] 3All ER 282; [1975]1 WLR 1093.

5 [1975] 2 Lloyd's Rep. 509.
} 
"We are told that an injunction of this kind has never been done before. It has never been the practice of the English courts to seize assets of a defendant in advance of judgment, or to restrain the disposal of them. It seems to me that the time has come when we should revise our practice. There is no reason why the High Court or this Court should not make an order such as is asked for here." 6

His main reason for allowing the applications was strong prima facie proof that the hire was owing and unpaid. He added that if such injunction was not granted, monies might be removed out of jurisdiction and the shipowners would have the greatest difficulty in recovering anything. ${ }^{7}$

The scope of a Mareva injunction was later expanded whereby the presumption that a Mareva injunction should only be confined to foreign based defendant was transformed so as to include non-foreign based defendant or local defendant. Another major development was the availability of a Mareva injunction to be used to freeze the disposal of assets located outside the jurisdiction. ${ }^{8}$ This was even better by virtue of s 25 of the Civil Jurisdiction and Judgments Act 1982 as extended in 1997, which gives the English Court power to grant free-standing interim relief in aid of foreign proceedings anywhere in the world and also to freeze future assets. Being an equitable remedy, the scope of the Mareva injunction or better known in England as freezing order ${ }^{9}$ has been much

[1975] 3 All ER 282, at 283.

Ibid., at 283.

This resulted from four decisions in the Court of Appeal, which were all decided in the spring of 1987.The cases are Babanaft International Co. SA v Bassatne and Another, [1989] 1 All ER 433. Republic of Haiti and others v Duvalier and other [1989]1All ER 456, Derby \& Co. Ltd. and others v Weldon and others (No1) [1989] 1 All ER 469 and Derby and Co. Ltd v Weldon (Nos 3 \& 4) [1990] 1 Ch 65, Each case contain fully reasoned decisions that Mareva injunctions and ancillary disclosure orders could be granted in relation to assets abroad.

When The English Procedural Rules was introduced in 1998 to replace the Rules of Supreme Court, the Mareva injunction was renamed as the freezing order and a standard form can be found under this Rule. In Australia Mareva injunction is known as 'asset preservation order.' See Cardile v LED Builders Pty Ltd (1999) 198 CLR 380; 162 ALR 294. 
expanded and enlarged and the development has been supported both by the judicial decisions and also the legislature.

In Malaysia, matters relating to injunctions is nothing new. It has adopted most of the kinds of injunctions available under English law. Provisions on injunction can be found under the Specific Relief Act 1950. ${ }^{10}$ This Act mentions a few types of injunctions, namely, temporary, perpetual and mandatory injunction. Temporary injunctions are the types that continue until a specified time or until the further order of the court. Procedurally, this is also known as interim and interlocutory injunction. ${ }^{11}$ There are many types of interlocutory injunctions and all these are creations of English judges. The ones which can be considered as harsh in nature but very useful in commercial law are the Mareva injunction and Anton Piller Order. ${ }^{12}$

\section{APPLICATION OF MAREVA INJUNCTION IN MALAYSIA}

The implementation of the Mareva injunction did not get a good start in Malaysia. Besides the initial reasoning that the Malaysian court had no jurisdiction to grant such relief, a legal remedy available under the Debtors Act 1957, to attach of property before judgment was said to be an obstacle to the introduction of the Mareva injunction. This can be seen in Zainal Abidin bin Haji Abdul Rahman v Century Hotel Sdn. $B h d,{ }^{13}$ the first case on the Mareva injunction in Malaysia. In the High Court, Hashim Yeop Sani J. held that the remedy sought by the plaintiff, that is the Mareva injunction, was unknown to Malaysian law. He further said:

"The only remedy available to the plaintiff before judgment according to our law is provided by section 19

\footnotetext{
$10 \quad$ Part III of the Specific Relief Act 1950 is on the topic of Preventive Relief.

11 Section 51(1) of the Specific Relief Act 1950. The provision further stated that "They may be granted at any period of a suit, and are regulated by the law relating to civil procedure."

12 Described as 'the law's two nuclear weapons' by Donaldson LJ in Bank Mellat v. Kikpour [1985] FSR 87.

13 [1982] 1 MLJ 40, at 43.
} 
of the Debtors Ordinance 1957 upon satisfying the court of the requirements of that section."

On appeal, ${ }^{14}$ Raja Azlan Shah CJ overturned the decision of the High Court and held that the Malaysia Court had jurisdiction to grant a Mareva injunction in appropriate circumstances and he emphasised that this was needed in order to fulfil the needs of businessmen. He stated:

"In such a situation where foreign businessmen including foreign multinational corporations have injected large sums of money and have substantial assets in this country, it would be a potential vehicle of injustice if the plaintiff is denied the facilities afforded by a Mareva injunction against the foreign defaulter who may try to dissipate his funds and assets in this country."

The above judgment indicates that the purpose for adopting the principles of the Mareva injunction was due to the increase of foreign investors holding substantial investments in Malaysia. ${ }^{15}$ As more incentives ${ }^{16}$ were being offered in the early 1980s to encourage foreign

[1982] 1 MLJ 260.

15 Besides that Malaysia's involvement in trade and investment around the world, be it within Asean, Asia or worldwide has increased. How far this is true, can be seen by a cursory perusal on the level of growth in the Malaysian economy. During the 1970s, the Malaysian economy has grown at the average annual rate of 7.8 percent and 5.9 percent during the 1980s. Moreover, the 1990 Malaysian GNP (of M\$110m) is only 0.7percent of the US GNP of US\$5,462 billion and 13.8 per cent of the Japanese GNP of US\$2,942 billion. Dato Malek Merican, “Towards Attaining A Competitive and Resilient Economy By the Year 2020 - The External Dimension,” A paper presented at National Seminar Towards A Developed And Industrialized Society: Understanding The Concept, Implications and Challenges of Vision 2020 at the Prime Minister's Department on 5-7 December 1991.

The security of foreign investment in Malaysia is strengthened through many investment guarantee agreements which the government has entered into with some foreign governments. Among the agreement is the bilateral agreement on double taxation on earnings. The government of Malaysia has also enacted various main legislation that provide the 
companies and industrialists to invest in Malaysia, ${ }^{17}$ a proper legal protection in form of preventive relief was needed to accommodate them. The Mareva injunction is a type of preventive relief which can be applied prior to trial and it can be ex parte or inter partes in nature. It is by itself an order which seeks to freeze the assets of the party against whom it is ordered up to the maximum point as stated in the order. ${ }^{18}$ The main reason behind this is to prevent any defendant from disposing its assets prior or during trial so as to leave the plaintiff with nothing remaining to satisfy a judgment which might be obtained against the defendant. Hence, the issue on the existence of attachment before judgment as an obstacle in the introduction of the Mareva injunction in Malaysia has been resolved by Edgar Joseph Jr, in Pacific Centre Sdn Bhd v United Engineers (Malaysia) Bhd ${ }^{19}$ whereby the judge had proposed seven differences between these two remedies.

basis for various incentives. Besides these, the Malaysian government maintains an open economy with liberal exchange control regime, which permits the free movement of capital and repatriation of profits. See; Tan Sri Dato' Haji Mohamed Salleh bin Abbas, “Foreign Investment in Malaysia, (1977)" MLJ, at xi-Xv.

$17 \quad$ The policy of the government towards foreign investments remains the same. There are many incentives given, especially attractive tax incentives. For example, Malaysia's corporate tax rate is attractive at $27 \%$ and is applicable to both resident and non-resident companies. Malaysia also offers a wide range of tax incentives for manufacturing projects under the Promotion of Investments Act 1986 and the Income Tax Act 1967. The main incentives are the Pioneer Status, Investment Tax Allowance, Reinvestment Allowance, Incentives for High Technology Industries and Incentives for Strategic Projects and Incentives for the Setting-up of International/ Regional Service-based Operations. Besides tax incentives,, Malaysian government practice the liberal equity policy. Effective from 17 June 2003, 100\% foreign equity holding is allowed for all investments in new projects, as well as investments in expansion/diversification projects by existing companies irrespective of their level of exports: http:// www.mida.gov.my/beta/

$18 \quad$ Pharmmalaysia Sdn.Bhd v Dinesh Kumar Jashbhai Nagjibha Patel \& Ors (No 2) [2005] 5 CLJ 50. per Abd Malik J. [1984] 2 MLJ 143, at 45. 
As far as Malaysia is concerned, presently, the question on jurisdiction to grant Mareva injunction is no longer an issue. The statutory provisions ${ }^{20}$ relevant to the issue of Mareva injunction have been examined by the courts in a series of cases. ${ }^{21}$ In Malaysia courts have adopted three guidelines introduced by Lord Denning in Third Chandris Shipping Corporation and other $\mathrm{v}$ Unimarine $S A^{22}$ and these have become the main elements that the court need to look at before granting any application for the Mareva Injunction. First, the plaintiff must show that he or she has a good arguable case. ${ }^{23}$ Secondly, the plaintiff must produce evidence

Schedule of the Courts of Judicature Act 1964, Order 92 rule 4 of the Rules of High Court 1980, Order 29 of the Rules of High Court and section 50 of the Specific Relief Act 1950.

Order 92 rule 4 of the Rules of the High Court 1980 provides:

"For the removal of doubts it is hereby declared that nothing in these rules shall be deemed to limit or affect the inherent powers of the Court to make any order as may be necessary to prevent injustice or to prevent an abuse of the process of the Court."

Zainal Abidin v. Century Hotel Sdn Bhd, [1982] 1 MLJ 260, Pacific Centre Sdn. Bhd v United Engineers Malaysia Bhd [1984] 2 MLJ 143, Aspatra Sdn Bhd \& 21 Ors. v Bank Bumiputra Malaysia Bhd. \& Anor [1988] 1 MLJ 97. Do note that after these cases, matters relating to jurisdiction has no longer being highlighted. Most cases accepted the statutory jurisdiction mentioned in all these cases. See Bank Bumiputra (M) Bhd v Cheong Yoke Choy (Malaysian Central Depository Sdn Bhd, Proposed Intervener) [2000] 7 MLJ 323. [1979] 2 All ER 972, at 784. The five guidelines are as follows; Firstly, the plaintiff should make full and frank disclosure of all matters in his knowledge that are material for the judge to know. Secondly, the plaintiff should give particulars of his claim against the defendant by stating the ground of his claim and the amount thereof, and fairly stating the points made against it by the defendant. Thirdly, the plaintiff should give some grounds for believing that the defendant has assets in the jurisdiction. Fourthly, the plaintiff should give some grounds for believing that there is a risk of the assets being removed before the judgment or award is satisfied. The mere fact that the defendant is abroad is not by itself sufficient and finally, the plaintiff must give an undertaking in damages, which in a suitable case should be supported by a bond or security.

23 See Bank Bumiputra Malaysia Berhad v Lorrain Osman \& Ors [1985] 2 MLJ 236. 
that the defendant has assets within the jurisdiction, and lastly, that there is a risk of the assets being removed before the judgment is satisfied. ${ }^{24}$

The important evolution of the Mareva injunction in the UK to attach assets on a worldwide basis, has so far, not been replicated in Malaysia. If the occasion arises, it is submitted that the local courts will rise to the challenge. Although they can derive jurisdiction from wide statutory provisions, based on previous experience they will most probably confine themselves to adopting principles from English case law with its inherent limitations due to the settled position that the worldwide Mareva injunction holds in England and Wales. ${ }^{25}$

In the case of Bank Bumiputra Malaysia Bank Bumiputra Malaysia Berhad \& Ors $v$ Lorraine Osman \& Ors,${ }^{26}$ an order for Mareva injunction was granted to freeze assets of defendant not only located in Malaysia but also in Hong Kong and England. There was no specific discussion on worldwide issue despite the fact that such order applied to assets located outside jurisdiction. Nevertheless in Kwasho International (HK) Ltd v Jayawealth Sdn Bhd \& Ors, ${ }^{27}$ it was held that the Mareva injunction can be granted not only in cases there is

${ }_{24} \quad$ Pacific Centre Sdn Bhd v United Engineers (Malaysia) Bhd [1984] 2 MLJ 143; Ace King Pte Ltd v Circus Americano Ltd \& Ors [1985] 2 MLJ 75.

The existence of a strong international reciprocity for the recognition and enforcement of judgment in relation to the defendant's assets abroad among European countries has contributed to the birth of worldwide Mareva injunction in England and Wales. The Convention on Jurisdiction and the Enforcement of Judgments in Civil and Commercial Matters (Judgment Convention) which can be found in the EEC Treaty, was signed in Brussel on $27^{\text {th }}$ September 1968 by originally six member states of the community. It was later extended to the United Kingdom. Ireland and Denmark by the Convention on Accession on $9^{\text {th }}$ October 1978. The main provision under this convention that allowed the application of the Mareva injunction worldwide is Article 24. The enforcement of this Article can later be seen under section 25 of the Civil Jurisdiction and Judgment Act 1982. Later such jurisdiction was extended to non-convention countries and to proceedings outside the scope of convention by the Civil Jurisdiction and Judgment Act 1982 (Interim Relief) Order 1997.

26 [1985] 2 MLJ 236.

$27 \quad$ [1992] 2 CLJ 1213, at 1217. 
dissipation of assets within the jurisdiction but also in cases of removal of assets out of jurisdiction. This judgment indicated the court's willingness to extend the application of the Mareva injunction in Malaysia to assets located out of jurisdiction

The sole purpose of the Mareva injunction is to prevent a plaintiff from being cheated out of the proceeds of action, a successful, by a defendant transferring his assets abroad or dissipating his assets within the jurisdiction. The remedy is not intended to give a plaintiff priority over those assets, or to prevent a defendant from paying his debts as they fell due, or to punish him for his alleged misdeeds, or to enable a plaintiff to exert pressure on him to settle an action. ${ }^{28}$ Hence in some circumstances the grant of Mareva injunction may cause incalculable harm and damage to the defendant. ${ }^{29}$ Another important fact is the extension of the Mareva injunction which may affect assets which are in the hands of any third party. Hence, the need to protect the interests of a third party will still be a paramount consideration and it will prevail over the interests of the plaintiff. ${ }^{30}$

\section{ANALYSIS ON SELECTED REPORT CASES RELATING TO THE MAREVA INJUNCTION IN MALAYSIA}

Throughout 1984 to January 2008, more than $60 \%$ of all reported cases on the Mareva injunction related to contract. This shows that the majority of applications for freezing assets are actively made by creditors who wish to protect their interest prior to trial. Although the creditordebtors' relationship varies, the fear of assets to be removed from jurisdiction by foreign defendant can never be overstated. This is the reason why Mareva injunction was first introduced by Lord Denning back in 1975, i.e to prevent the dissipation of assets by a foreigner. In the local case of Poly Electronic \& Electrical (M) Sdn Bhd v Daewood Corp (No 1) ${ }^{31}$ Abdul Malik J had granted the Mareva injunction together

\footnotetext{
$28 \quad$ Pharmmalaysia Sdn.Bhd v Dinesh Kumar Jashbhai Nagjibha Patel \& Ors (No 2) [2005] 5 CLJ 50.

$29 \quad$ Comtrac Sdn Bhd v Arah Cipta Sdn Bhd. [2004]1 LNS105.

$30 \quad$ Wako Merchant Bank (Singapore) Ltd v Lim Lean Heng \& Ors, [2003] 5 MLJ 233.

$31 \quad$ [2003] 2 MLJ 310.
} 
with the tracing order against the defendant, a Korean company and all its directors, citizens of South Korea. What has been emphasized here was plainly the prevention of abuse by foreign residents causing assets to be removed from the jurisdiction in order to avoid the satisfaction of any judgment in proceeding pending in this country.

Creditor-debtors' relationship has always been the main reason behind the application of Mareva injunction. In Wako Merchant Bank (Singapore) Ltd v Lim Lean Heng \& Ors, ${ }^{32}$ the defendant was indebted to the plaintiff under a judgment obtained in Singapore. This judgment was registered as the judgment by the High Court of Malaya under the Reciprocal Enforcement of Judgment Act 1958. In order to secure the property in Malaysia, the plaintiff applied for ex-parte Mareva injunction so that the first defendant will not dissipate his assets in order to avoid execution to satisfy the judgment. The court granted ex-parte Mareva and since the duration was limited, the plaintiff made an application inter parte which was opposed by the second to sixteenth defendants on the ground that the property affected belonged to them, as disclosed in affidavits. ${ }^{33}$

Mareva injunction has also been used in an effort to prevent disposal of property or assets in the case involving breach of trust. This has been well illustrated in the ever celebrated case of Bank Bumiputra Malaysia Berhad \& Ors $v$ Lorraine Osman \& Ors ${ }^{34}$ The plaintiff brought an action against the defendant who happened to be a director of the first plaintiff company and chairman of the Board of Directors of the second plaintiff company (a wholly subsidiary of the first plaintiff)

$32 \quad$ [2003] 5MLJ 233.

33 Abd Aziz J in granting the plaintiff's application to cross-examine the deponent of the affidavit said: "It seemed to me that the question to be answered was whether, in a Mareva application, if a person other than the defendant claims an asset that the plaintiff seeks to preserve by the injunction on the contention that it is the property of the defendant, the question of the true ownership has to be determined. If it has to be determined, then if there is conflict of affidavit evidence on any matter relevant to the question of ownership, and the conflict cannot be resolved by rejecting the evidence of one side for any of the reasons stated by Lord Diplock, then the matter of the conflict has to be determined by examining the makers of the affidavits so that the question of true ownership may be determined.” Ibid at 238. 
whereby the plaintiff alleged that the defendant received the sum of RM 27,652,835 without the knowledge and approval of the plaintiffs and in breach of his fiduciary duty as director and chairman. As the plaintiff considered it as secret profits, an ex-parte application for Mareva injunction was made to restrain the defendant from transferring his assets out of jurisdiction. The defendant was also required to make disclosure as to the value, nature and whereabouts of his money, with reference to 32 other banks and 102 other companies.

Interestingly, several companies which were affected by the Mareva order applied for this order to be set aside and this can be seen in the case of Aspatra Sdn Bhd \& 21 Ors v Bank Bumiputra Malaysia Bhd \& Anor (BBMB). ${ }^{35}$ Aspatra Sdn Bhd and others were among the companies affected by the Mareva proceedings brought by BBMB against Lorraine Osman and in this case they were allowed to be joined as inteveners. They applied for this order to be set aside. Among the issues discussed was whether the High Court judge was correct in lifting the corporate veil of the interveners and in holding that the assets of the interveners were assets of Lorrain. The court held that it could generally lift the corporate veil in order to do justice particularly where an element of fraud is involved. In this case there was an element of fraud in the receipt of secret profits and this was sufficient for the court to lift the corporate veil for the purpose of determining whether the assets were really owned by the company or by Lorrain.

A different approach was taken in the 1998 case of Dato' Kam Woon Wah v Mohd Jalil bin Sarip, ${ }^{36}$ whereby the judge held that the test of the Mareva injunction must be altered and varied according to the nature of the case and in this case, the plaintiff applied for a Mareva injunction in a libel action. The defendants wrote a letter to a Judicial Commisioner referring to the consent order recorded by the parties and basically the letter explained various arbitrary and unlawful acts taken by the plaintiff in an attempt to dispose a piece of property. The plaintiff took offence to the contents of the letter and sued defendant for defamation. The writ for this application was accompanied by a summons in chambers seeking a Mareva injunction to restrain the defendant from removing any of his assets from the jurisdiction of the court. The plaintiff 
argued that the defendant had no other assets within the jurisdiction and would take steps to dissipate the property

The defendant contended in his defence that the Mareva injunction was not applicable to a defamation suit. This basically involved two prospective actions and there was a fundamental difference between the Mareva injunction and a libel action. A higher standard of proof, was required in an application for an interim injunction to restrain publication of defamatory material whereas in an application for the Mareva injunction, only a good arguable case must be shown, otherwise in the words of James Fong J:

\begin{abstract}
"it becomes easier to secure a Mareva injunction against the property of the defendants before judgment than to obtain an interim injunction to restrain publication of alleged defamatory material before trial considering the fact that in both these applications the questions of whether there is defamation or no defamation can only be determined at trial." ${ }^{37}$
\end{abstract}

In this case the requirement for a Mareva injunction must, therefore be subject to where the defamatory statement is so obviously untruthful' or where the plaintiff had satisfied the court that the defendant will fail. ${ }^{38}$ This is one of the cases where the Malaysian court refused to follow English principles and the decision was made in accordance with Malaysian needs, as is the court's discretion to do so. Ultimately, flexibility is shown and the advantage here lies upon the fact that the Mareva injunction is an equitable remedy, which is usually granted, not only based upon inherent jurisdiction, ${ }^{39}$ but also subject to the discretionary power of the judge.

37 209.
The judge refused to follow the decision of the Singapore court in Lee
Kuan Yew v Tang Lian Hong \& other action, whereby in this case a
Mareva injunction was granted against the defendant on a defamation
case brought by the plaintiff. The judge applied the conventional
approach of good arguable case, or that there are serious questions to
be tried. Further they have to prove by 'solid evidence' that there is a
real risk of a defendant dissipating his assets here and abroad, before
a judgment or award is satisfied.
RHB Bank Bhd v. Zalifah Juan \& Anor [2005] 4 CLJ 430.


As far as requirements for Mareva injunction is concerned, most of the judges in Malaysia opine that a good arguable case must exist in all such applications ${ }^{40}$ There is no detailed distinction made on the 'good arguable case' requirement in Mareva injunctions and interlocutory injunctions. However in some cases, in determining the element of 'good arguable case,' a phrase such as "likely to recover judgment” is used, or the judge will consider whether the defendants have an arguable defence. ${ }^{41}$ Nevertheless, it has been stressed by Gopal Sri Ram JCA in Hock Hua Bank (Sabah) v Yong Liuk Thin, ${ }^{42}$ that it is extremely relevant that a higher standard of proof is required in establishing a good arguable case in Mareva applications compared to the usual application for an ordinary injunction. ${ }^{43}$ This was done by considering the connection between the defendant's strength and weakness in defence, filed at the earlier stage of the action. The court will refuse to grant Mareva injunction if the fundamental element of good arguable case cannot be fulfilled. The Court of Appeal in Wong Ho Enterprise Sdn.Bhd. \& Ors v. Tiong Hoo Teck ${ }^{44}$ held that the High Court was wrong in not considering the payment certificate has not been approved by Ministry of Education. The fact that the claim was not finalized and approved caused uncertainty to the

$40 \quad$ Aspatra v Bank Bumiputra Malaysia Berhad [1988] 1 MLJ 97; Algemene Bank Nederland N.V v Metromewah Sdn Bhd \& 3 Ors [1991] 2 CLJ 1493; Ang Chee Huat v Engelbach Thomas Joseph [1995] 2 MLJ 83; Creative Furnishing Sdn Bhd v Wong Koi [1989] 2 MLJ 153 at 155; Pacific Centre Sdn Bhd v United Engineers (Malaysia) Bhd [1984] 2 MLJ 143; Ace King Pte Ltd v Circus Americano Ltd \& Ors [1988] 2 MLJ 75; KSM Credit \& Leasing Sdn Bhd v Datamaute (M) Sdn Bhd \& Ors [1986] 1 CLJ 500. Foo Sam Ming v Dato Matshah Safuan [1993] MLJU 219; Tsoi Ping Kwan v Loh Lai Ngoh [1996] MLJU 71; Yukilon Manufacturing Sdn Bhd [No 4] \& Anor v Dato' Wong Gek Meng \& Ors [1998] MLJU 60.

$41 \quad$ Lien Hoe Sawmill Co. Sdn Bhd. v Yap Sing Hock \& 2 Ors [1992] 2 CLJ 1022. In this case although the defendants have an arguable defence, they do not have so much defence to convince the court that the plaintiff's good arguable case cannot succeed. The plaintiff still has a good arguable case.

$42 \quad$ [1995] 2 MLJ 213.

43 In this case reference was made to the English case of The Tatiangela [1980] 2 Lloyd's Rep 193.

$44 \quad$ [2008] 3 MLJ 321 at 324-325. 
cause of action and concurrently manifested into the non existence of a good arguable case.

\section{THE MAREVA INJUNCTION AND FAMILY DISPUTES}

Unlike England and Wales, where freezing orders can be considered as a useful tool in preventing any dissipation of matrimonial property ${ }^{45}$ in Malaysia, the situation is different. Despite the fact that the Mareva injunction is not fully utilized in the family context, a distinction was made in the case of Mangalam d/o Sinniah v Kattayat Mohandas s/o CP Narayanan Menon, ${ }^{46}$ by Faiza Thamby Chik J between Mareva injunction and interlocutory injunction in the pursuit to prevent a husband from dissipating matrimonial property prior to the hearing for divorce in order to preserve status quo. He observed that the wife in this case did not ask for the Mareva injunction and said:

"The principles applicable to Mareva injunction are not
relevant to interlocutory injunction under O 29 of the
RHC. A Mareva injunction is an equitable relief but not
an injunction to prevent the status quo of the subject
matter of litigation. It is an aid of execution. In deciding
whether the Mareva injunction should be granted there
must be a strong prima facie case before it is granted.
There is no such requirement in interlocutory injunction.
The American Cyanamid principle on interlocutory
injunction are not relevant to Mareva injunction which
is of a different character, for the successful application.
Mareva injunction will not obtain a perpetual injunction."

The husband complained that such injunction has brought great hardship to him and in trying to set aside the interim injunction, he relied on cases dealing with Mareva injunction. The High Court held that all these cases are not relevant and inapplicable to this case which involves

\footnotetext{
$45 \quad$ Section 37(2)(a) of the Matrimonial Causes Act 1973 gives the court jurisdiction to prevent someone from disposing their assets. 
interlocutory injunction and not the Mareva injunction. Indeed such distinction is important since the Mareva injunction has always been seen as a particular type of interlocutory injunction.

An interesting case can also be seen in Ismail Mohamad $v$ Wan Khairani Wan Mahmood \& Another ${ }^{47}$ where it involved a dispute between a divorced Muslim couple over the distribution of their assets. Both husband and wife were shareholders of a company and the wife owned $7.97 \%$ of the shares. The wife brought an action to the High Court as the shareholder of the company to protect her interest in the company relating to the proceeds of compensation to two parcels of land belong to company which had been acquired by the government and these proceeds were paid to the husband's personal account. The Court of Appeal granted an injunction to prevent the husband from dissipating the monies, equivalent to the wife's share in the company, held by the husband as a trustee. Both of them appealed to the Federal Court against the grant of partial injunction. The appeal by the wife was granted and the Federal Court granted an injunction to prevent the husband from dissipating $100 \%$ of the monies held by the husband for the company.

The wife in this case has taken similar action against the husband in relation to harta sepencharian in Syariah Court. The Court of Appeal when granted a partial injunction i.e preventing the husband to dissipate compensation money based on the wife's share, was of the view that there might be an overlapping jurisdiction between Syariah Court and the civil court if an injunction were to be granted in full. The Federal Court on the other hand decided that these two cases were different in nature. In the Syariah Court the wife claimed an injunction to prevent the husband to dispose his assets in order to protect her claim for the distribution of harta sepencharian. Nevertheless in the Civil Court the wife was seeking her right as a minority shareholder. Zaki Tun Azmi CJ in delivering the judgment of the Federal Court said:

"Her motive may be to protect her rights as a wife but that was irrelevant. One must view her application as one by a shareholder. It does not prevent her from doing so. It is not denied that if she had not filed an action to claim harta sepencharian in the Syariah Court, the 
objection to her filling the derivative action may not arise.”

\section{THE MAREVA INJUNCTION AND THE ARBITRATION ACT 2005}

Under the Arbitration Act 2005, a party may apply to a High Court for any interim measures and the High Court may make the orders, among others for the preservation, interim custody or sale of any property which is the subject-matter of the dispute ${ }^{48}$ and ensuring that any award which may be made in the arbitral proceedings is not rendered ineffectual by the dissipation of assets by a party. ${ }^{49}$ The High Court may also make orders for an interim injunction or any other interim measure. ${ }^{50}$ This application may be made before or during arbitral proceedings. In the case where an arbitral tribunal has already ruled on this relevant matter, the High Court shall treat any findings of fact made in the course of such ruling by the arbitral tribunal as conclusive for the purposes of the application. ${ }^{51}$ Besides the High court, the arbitral tribunal has power to order interim measures. ${ }^{52}$

In a restricted sense the term 'interim measures of protection,' usually refers to the preservation and protection of the subject matter of the dispute pending final disposal of the dispute. Standing on its own, the term 'interim measures' could equally refer to the interlocutory directions required for the orderly conduct of the proceedings. ${ }^{53}$ In the case of Ikatan Innovasi Sdn. Bhd v KACC Construction Sdn. Bhd, ${ }^{54}$ the relationship between the grant of Mareva injunction to parties partaking arbitration preceedings was discussed. It revolves around two paragraphs,

\footnotetext{
$48 \quad$ Section 11(1)(f) of the Arbitration Act 2005.

$49 \quad$ Section 11(1)(g) of the Arbitration Act 2005.

50 Other orders may include security for costs, discovery of documents and interrogatories, giving of evidence by affidavit, appointment of a receiver and securing the amount in dispute.

51 Section 11(2) of the Arbitration Act 2005.

$52 \quad$ Section 19 of the Arbitration Act 2005.

53 Dato’ Mahadev Shankar, “An Overview Of Malaysian Arbitration Law In 2002” [2003] 1 MLJ i; [2003] 1 MLJA 1.

54 [2008] 3 CLJ 48.
} 
namely (f) and (g) of section 11(1) of the Arbitration Act 2005. Abdul Aziz Rahim J in this case stated that despite the fact the High Court may make order for the preservation of any property, which is the subject matter of the dispute, in this case section 11(1) (f) of this Arbitration Act 2005 could not be applied as the dispute did not involve property but related to liquidated sum in form of payment under a contract.

Nevertheless para (g) of the same section, according to the judge, covers a wider scope, keeping aside the nature of property involved. The High Court may make such order as the court thinks just and appropriate in the circumstances in order to ensure the award that the applicant or plaintiff may obtain in the arbitration proceedings will not be rendered ineffectual and of no value, due to the defendant's dissipation.

\section{THE MAREVA INJUNCTION AND THE SYARIAH COURT}

Injunction under Syariah law is not something new. ${ }^{55}$ There are several provisions in the Al-Qur'an ${ }^{56}$ and Sunnah, ${ }^{57}$ the two primary sources of Islamic law that mention the concept of injunction be it in a mandatory or prohibitory form. Example can be seen in Surah al-Baqarah; ayat 231 whereby Allah says:

"When you divorce women and they fulfil the term of their iddah, do not prevent them from marrying their (former) husband if they mutually agree on equitable terms. This instruction is for all amongst you, who believe

$55 \quad$ Dr. Najibah Mohd Zin, “Injunksi Dalam Undang-Undang Islam dan Pemakaiannya di Mahkamah Syariah,” in the book edited by Tajul Aris Ahmad Bustami and ors, Isu-Isu Mahkamah Syariah. Harta Sepencarian Prosiding Ex-parte Perintah Injuksi, Pusat UndangUndang UIAM, 2003 at 106-119.

56 The very word of God, used by Muslim as guidance and reference in all matters. This is the main source of reference in the syariah and is supplemented by Sunnah, since the wording in Al-Qur'an is in a general form.

57 The action and saying of the Prophet and is a supplementary to the Al-Qur'an. 
in God and the last day. That is (the course making for) most virtue and purity amongst you."

This is considered an order whereby Islam sees the termination of marriage as a serious matter and nobody should prevent the reunion of the divorced couple if they have complied with every lawful device. ${ }^{58}$

Referring to the Sunnah of Prophet Muhamad (s.a.w) the injunction in the form of both mandatory and prohibitory order can be found in many hadiths. An example can be seen in the case where Abdullah bin Umar divorced his wife while she was menstruating. When his father Umar mentioned this to the Prophet (s.a.w), he said:

"Command him, he must take her back and keep her till she is purified, then has another menstrual period and is purified. Then if he desires, he may divorce her during the period of purity before he has intercourse with her. This is the divorce for waiting period as commanded by Allah, the Exalted." 59

This is an example where the order to take back a wife whom the husband has divorced during her menstrual period, as one of the requirement of divorce under Islamic law is that it need to be done when the wife is in the state of purity. ${ }^{60}$

In Malaysia, the usage of injunction in the Syariah court is only limited to several aspects as these matters have been dealt with under the Federal Constitution, bearing in mind that its application is limited within each state's jurisdiction. ${ }^{61}$ Although the practice is not as wide as in the civil court, there are several statutory provisions relating to injunction which can be found relating to Islamic Family Law. This can

$58 \quad$ A. Yusuf Ali, The Holy Qur'an, The Translation and Commentaries. Islamic Propagation Centre International, at 92-93.

$59 \quad$ Sunan Abu Dawud, Volume 2, at 600.

60 Despite the fact that divorce is lawful, it should be avoided as far as possible and it should be the last resort after means for conciliation failed. The approved method of divorce according to sunnah is that it should be done when the women is not in the state of menstrual.

$61 \quad$ Federal Constitution, List 11, Ninth Schedule. 
be seen in cases relating to prohibited marriages, ${ }^{62}$ prohibitory order to prevent the husband from abusing the wife, ${ }^{63}$ and also to enter into any transaction or transferring any property which may deprive the wife from receiving any maintenance and alimony.

There is yet an attempt made by Syariah Court to utilise the Mareva injunction. Although the concept of freezing assets is not something new under shariah, the matter of jurisdiction and procedures need to be taken into consideration. Despite the Shariah Court's jurisdiction being limited mainly to family matters, one cannot deny the fact the Mareva injunction is an effective tool to prevent dissipation of property pending the settlement of divorce. In a speech by Dato' Abdul Hamid bin Mohamad, ${ }^{64}$ on Judiciary and Legal System in Malaysia, he commented on the use of the Mareva injunction in order to prevent any dissipation of any jointly acquired property by the parties to a divorce. He acknowledged the fact that the civil court in Malaysia may order the Mareva injunction ex-parte and this may have effect on any property situated anywhere within jurisdiction. Unfortunately this is not the position with the Syariah Court and moreover being a remedy adopted from English law, the principles of Mareva injunction is not something familiar to the Syariah court judges. If the Syariah Court is able to grant such order it will only be effective within a particular state. If these properties are situated in four different states, there shall be four different applications and in the case of appeal, four different appeals. Matters will be worsened if all these Syariah Appellate Courts decide differently.

\footnotetext{
62 Islamic Family Law Act Federal Territory 1984, section 9.

63 Islamic Family Law Act Federal Territory 1984, section 107(2).

64 The speech was made when he was a judge in the Court of Appeal. He was the former Chief Justice of Malaysia. Dato Abd Hamid Mohamad; 'Sistem Kehakiman dan Perundangan di Malaysia: Satu Wawasan,' membincangkan kedudukan undang-undang sivil, undang-undang Islam, mahkamah sivil dan mahkamah syariah di Malaysia dan kemungkinan penyatuan kedua-dua mahkamah itu [2001] 4 MLJ clxxx; [2001] 4 MLJA 180.
} 


\section{CONCLUSION}

Injunction, particularly the Mareva injunction has so much to offer, in order to serve justice as an instrument of equity. This has to do with the fact that Mareva injunction ensures that the fruits of a judgment given in favour of the plaintiff, will not be frustrated by the act of the defendant. Courts in Malaysia are very adamant in stressing the fact that the Mareva injunction is indeed an equitable preventive relief. The very basic concept of balance of convenience has been used as one of the main considerations for the grant and refusal of Mareva injunction. ${ }^{65}$ The famous maxim of equity that 'He who seek equity must come with clean hands" is also one of the factors to be considered as the jurisdiction to grant a Mareva injunction. In Ikatan Innovasi Sdn Bhd v KACC Construction Sdn.Bhd, ${ }^{66}$ Abdul Rahim Aziz J. emphasized that if any of the parties come to court with their hands tainted with inequities then the court should not accede to their requests. In other words, the court cannot be used as an instrument to perpetrate injustice and that in the circumstance it will be a travesty of justice if the court does not consider the question as to where the justice of the case lies. ${ }^{67}$

Despite all these, the Mareva injunction is still one of the powerful tools in the form of preventive relief in Malaysia. The utilisation of this remedy can also be extended to cover fields from commercial law to family law and personal disputes, and the protection offered is not limited to the individuals solely but can also be extended to the public as a whole. This can be seen in an action to protect investors where the Securities Commission (SC) on 6 September 2007 obtained Mareva injunction to prevent The Ayer Molek Rubber Company Berhad (Ayer Molek) and its solicitors Messrs. Ropizah Ambri \& Co from disposing of or dealing with or dissipating any of its assets in or outside Malaysia up to the value of RM20 million, which represents the company's sale proceeds of several pieces of land in 2006 and 2007. This resulted from an investigation into

EHQ Projects Sdn.Bhd. \& Ors v. Equipro Sdn.Bhd \& Ors [2008] 7 CLJ 343, Brights Rims Manufacturing Sdn, Bhd. v. Victor Taichung Machinery Works Co Ltd \& Anor [2007] 4 CLJ 230.

$66 \quad$ [2008] 3CLJ 48.

$67 \quad$ Larut Cosolidated Bhd \& Anor v. Khoo Ee Bee \& Ors [1997] 5 CLJ 307 at 334 . 
the 2006 and 2007 sales of land made by Ayer Molek. The findings revealed that these sales were undertaken without the shareholders' approval and were in breach of paragraphs 10.04 and 10.06 of the Bursa Malaysia Listing Requirements. ${ }^{68}$ Although Mareva orders were introduced more than two decades ago, there are a few issues that need to be settled. The most pertinent issue will be the protection that is to be given to third party and this need to be solved in a very subtle way as there are many precedents which can be taken from other jurisdictions, especially from Australia and England. 